\title{
Alternative Tourism Development: A Theoretical Background
}

\author{
Eirini Triarchi (Corresponding author) \\ Lecturer, Department of Accounting and Finance \\ Technological Educational Institute of Epirus \\ 48100 Psathaki Preveza, Greece \\ Tel: 302-682-050-622Ｅ-mail: etriarhi@ @eiep.gr
}

\begin{abstract}
Kostas Karamanis
Associate Professor, Department of Accounting and Finance

Technological Educational Institute of Epirus

48100 Psathaki Preveza, Greece

Tel: 302-682-050-555Ｅ-mail: kkaraman@teiep.gr
\end{abstract}

Received: October 5, 2016

doi:10.5296/wjbm.v3i1.11198
Accepted: May 4, 2017

Published: May 10, 2017

URL: http://dx.doi.org/10.5296/wjbm.v3i1.11198

\begin{abstract}
This paper presents the development of tourism market through the alternative forms of tourism. Origins and main definitions are presented followed by an analysis of the complexity of classifying the alternative forms of tourism. It is about developing new forms of sustainable tourism that integrate local populations and both natural and human environments of host countries. Ecotourism, cultural tourism and creative tourism support a different philosophy of tourism. Ecotourism in recent years encloses many tourism forms focused on natural environment. In the concept of alternative tourism, the dynamic growth of cultural tourism can be explained by the fast growth of demand for trips to various cultural attractions and amenities. The increase of educated population around the world, the globalization and technology supported this growth. Cultural tourist, from consumer is transforming to producer of the cultural products and experiences. Since this type of tourist becomes more interactive and creative, cultural tourism needs to be repositioned and become more "creative" too. In this way, the present article provides a simplified approach of the new "alternative" tourism development and distinguishes the current trends in tourism market.
\end{abstract}

Keywords: Alternative forms of tourism, Ecotourism, Culture tourism, Creative tourism 


\section{Definitions and Concepts}

Although tourism has been acknowledged for its tremendous economic and social benefits, being an economic saviour providing jobs and increasing GDP, it has also been accused as a source of a wide range of serious problems, especially in developing economies. Especially, the fact that it creates huge economic leakage, in the sense that the major investments in tourism come from western multinational enterprises (MNEs) in which the income from tourism sector would flow back (Smith, 1989). Macleod (2004) supports that tourism changes the composition of the working population from traditional industries of agriculture to service based tourism and hospitality industries, disturbing the community and its cultural identity. Four main influential phenomena led to the need of a different approach in tourism. These are: 1) economic issues like the fact that economic growth did not solve the poverty problem, 2) environmental issues referring to mass tourism influence on the environment, 3) political issues reflecting the political economy of the international tourism industry which turned to be a natural continuation of historical inequalities between the First World and the Third World, and 4) social issues including the new traveller market of post-modern culture.

Thus, the "new" form of tourism aroused and many people accepted it instinctively even though they could not precisely defined it. Still, today is surprising that no universally agreed or widely adopted definition of alternative tourism is to be found, nor that few explicit lines between its different forms have been made. This different approach would have fewer and less severe negative effects on destination areas and their populations, and would still enjoy the positive economic effects, appearing as the optimal solution. This new "form" of tourism emerged as an alternative solution to the most undesired type of tourism "the mass tourism" or "the conventional/commercial tourism" or "the traditional tourism".

It is alternative to large numbers of visitors, to clumsy and unregulated development, to environmental destruction, to social alienation and homogenization. "Mass tourists" enjoy the convenience of not having to make their own travel arrangements, not having to spend a large amount of money or time, not to be obliged to learn a foreign language in order to buy goods and enjoy services in their tourist destination. This type of tourists are ready to abandon the genuine authentic local cultural contact, and the Third World or Old World seemed to provide these benefits to them (Butler, 1992).

Eventually, the "new" forms of tourism made their appearance in developing countries between the 1970s and early 1980s, in order to tackle the hard mass tourism. These forms of tourism served a more sensitive approach giving priority to natural and cultural resources at the front line of planning and development. Although, they appeared in different names and various models they shared the same values, to improve situation and to preserve the original rural appeal of the touristic destination. They involved projects that were small-scale, involving low-level of investments, low-key in nature, independent and self-sustaining and demanding the high participation of the local inhabitants (main characteristics are presented on Table 1). The involvement of local population would improve contacts between locals and their foreign guests would offer a more authentic, meaningful and satisfying experience for both visitors and hosts. Dernoi in 1981 related the term "alternative tourism" to the 
accommodation style as "in alternative tourism the client receives accommodation directly in or at home of the host with, eventually, other services and facilities offered there" (Dernoi, 1981, pp. 253-264). Few years later, he added other features to alternative tourism that distinguished from mass tourism, resulting to the fact that in alternative tourism individuals, families, or local communities offer privately to the visitors a set of hospitality services. Thus, alternative tourism aims at establishing direct personal and cultural intercommunication and understanding between the host and the visitor (Dernoi, 1988). This definition supports the facilitation and improvement of contacts between visitors and locals, in order a cultural exchange and intercommunication of both parties, to be obtained. Donald Macleod (1998) suggests a number of principles for giving a better definition of alternative tourism and Herms (2006), evolved these principles to the followings:

a) It should be based on dialogue with the locals which must be informed of its effects,

b) It should be environmental friendly and attributing respect to local culture and to religious tradition,

c) The scale of tourism should be adjusted to the capacity of the local area to cope, measured in aesthetic and ecological terms.

According to Holden, alternative tourism "is a process which promotes a just form of travel between members of different communities. It seeks to achieve mutual understanding, solidarity and equality amongst participants" (Holden, 1984, p. 15: cited in Smith \& Eadington, 1992, p. 18). Holden is mainly interested in evolving the interrelation of guests and hosts, through the setting of well-organized special interest tours, rather on actual development of facilities. Thus, alternative tourism is described as 'forms of tourism that are consistent with natural, social, and community values and which allow both hosts and guests to enjoy positive and worthwhile interaction and shared experiences' (Smith \& Eadington, 1992, p. 3).

In Europe, especially in Germany, Austria and Switzerland, in the early 1980s, the term that was used to explain the new form of tourism was "soft tourism" as its main feature was the attention to environmental issues and the promotion of ecologically friendly development policies. Chur Declaration of the "Commission Internationale Pour La Protection des Regions Alpines" (CIPRA) defines soft tourism as "the mutual understanding between the local population and the guests, which does not endanger the cultural identity of the host region and which endeavours to take care of the environment as best as possible. Soft tourists give priority to using infrastructures destined to the local population and do not accept substantial tourist facilities harmful to the environment" (Broggi 1985, p. 286 cited in Pearce, 1992, p. 18).

The term "New Tourism" was proposed in 1979 by Rosenow and Pulsipher, for the American tourism industry as a new way to growth, claiming that not only the visitors, but also the communities would be benefited by the establishment of a "differentiated" tourism industry based on unique assets of both. "New Tourism" is built on eight principles: 1) unique heritage and environment, 2) evolving special quality of attractions, 3) effort to developing additional 
local attractions, 4) economic opportunity and cultural enrichment, 5) local services, 6) marketing communication, 7) adjustment of assets to local carrying capacity and 8) prevention of energy-losses.

The use of the term "alternative tourism" might be seen as problematic, since nowadays is usually related to the principle of sustainable development. Thus, making the term "sustainable tourism" more accurate in describing the "new" forms of tourism. According to Holden (2003), the sustainable tourism is more compatible with the natural environment than the conventional mass tourism. Vegetation, animal habitats, and prime agricultural land made the way for new infrastructure through deforestation which harmed the ecosystem and landscape (Holden, 2003; cited in Wearing \& Grabowski, 2011). According to UNWTO "sustainable tourism development guidelines and management practices are applicable to all forms of tourism in all types of destinations, including mass tourism and the various niche tourism segments. Sustainability principles refer to the environmental, economic, and socio-cultural aspects of tourism development, and a suitable balance must be established between these three dimensions to guarantee its long-term sustainability" (UNEP \& UNWTO, 2005). Sustainable tourism is becoming so popular that some argue that what presently it is called 'alternative' will be 'mainstream' in a decade.

Table 1. Alternative forms of tourism-main characteristics

\begin{tabular}{|c|c|c|}
\hline Management & Regulation & Contribution in economy \\
\hline $\begin{array}{c}\text { The development process is low } \\
\text { and controlled development, } \\
\text { planned-pace is not so important, } \\
\text { concept-centre, }\end{array}$ & $\begin{array}{c}\text { Local community control's, Local } \\
\text { decision- making }\end{array}$ & $\begin{array}{c}\text { Role of tourism is } \\
\text { Amount: Extensive; minimizing local } \\
\text { complementary to the existing } \\
\text { activity } \\
\text { Impacts awareness turn to reduce } \\
\text { negative effects }\end{array}$ \\
$\begin{array}{c}\text { The developer is local } \\
\text { Ideology with respect to public } \\
\text { intervention in the development } \\
\text { inefficient in saving fuel }\end{array}$ & $\begin{array}{c}\text { pinkages and leakage are } \\
\text { respectively mainly internal } \\
\text { and minimal }\end{array}$ \\
& Emphasis on community stability and & influences. \\
& well-being; integrated, holistic & High income distribution \\
& Its time frame is long-term & \\
\hline
\end{tabular}

Note. Authors elaboration from Weaver, 1998 (p. 10), Hunter \& Green, 1995 (p. 81), Butler, 1992 (p. 38).

\section{Alternative Forms of Tourism: Classification's Issues}

Since the "new" tourism arrived, many forms of it have been emerged gradually which sources are found in many different aspects of contemporary economic and social life. The special groups of "new" tourists are seemed to be motivated to travel for different reasons, formulating both similar and controversial types of alternative tourism. This is to one point a consequence of the fact that even though alternative tourism has been receiving ever-growing 
academic attention, the differences in its interpretation by various academic caused the definition and terminology for the alternative tourism to be contentious. Academics seem to agree only to their opposition towards package or mass tourism. Others suggest that "the alternative tourism paradigm must be examined as an overarching umbrella term, under which the diversity of other forms of tourism or niche markets lay" (Benson, 2005). Sometimes, ecotourism or sustainable tourism or justice tourism are described as synonymous to alternative tourism and other times as its different forms, making classification complicated. In this part, some of the main different approaches that lead to specific classifications will be presented.

There are several facets of alternative tourism that nurture societal and ecological restructuring, naturally of interest would be ecotourism, sustainable tourism, pro-poor tourism (PPT), fair trade, community-based tourism, peace through tourism, volunteer tourism and justice tourism (Isaak, 2010) . Eco-tourism is acknowledged as one of the best ways to conjoin economic development with environmental sustainability. Butler's concept of sustainable tourism is that of 'tourism in the context of sustainable development'.

PPT appeared lastly and is more an approach to tourism development and management. It is aiming in strengthening relations between tourism businesses and poor people, in the sense for the tourism sector to support the elimination of poverty and for poor people to have the opportunity to participate to the development of the touristic product. It is expected that PPT will improve the quality of local inhabitants' life.

Peace through tourism focuses on the kinds of tourism that favour more peaceful relations. The formal way to explain the connection between tourism and peace is, to assure that the cross-cultural international tourism nurtures harmonious relations. Peace tourism can contribute to reconciliation of two nations and generally of juxtaposed groups of people in conflict situations, securing their co-existence (Isaak, 2010).

Volunteer tourism emerges as a response to growing social and environmental issues in developing countries and as a response to physical disasters and terrorism's attacks. It includes short-term projects with the intention of serving communities in need. According to Wearing, volunteer tourists have been defined as those who "volunteer in an organized way to undertake holidays that might involve aiding or alleviating the material poverty of some groups in society, the restoration of certain environments or research into aspects of environment" (Wearing, 2001, p. 1; cited in Wearing \& Grabowski, 2011, p. 149).

Justice tourism has only recently been given a name and recognized as an emerging trend. Some authors equate justice tourism to alternative tourism, based on Holden's definition (1984) of alternative tourism as "a process which promotes a just form of travel between members of different communities. It seeks to achieve mutual understanding, solidarity and equality amongst participants". Justice tourism tries to humanize the tourism industry, in the sense that, "oppressed people are engaging with the tourism sector to offer heritage tours, and these tours can endorse visitors' understanding of human rights and justice issues while at the same time giving voice to the local communities to speak for themselves and tell their own stories of current oppression and occupation" (Isaak \& Hodge, 2011, p. 103). 
Angela Benson (2005) suggests "research tourism" to be contextualised within the "alternative tourism paradigm" and more specifically to the educational, scientific and volunteer sectors. Modern "educational" tourism refers to opportunities that colleges and universities offer to travel and study abroad. It includes "school trips and language schools, university and college students in terms of study abroad, fieldtrips and exchanges, and the adult and seniors market, including cookery, art, gardening courses in exotic locations, and specialist organisers and nature-based and cultural educational tourism programmes" (Carr \& Cooper, 2003, Carr, 2003, Ritchie, 2003; cited in Benson, 2005). Mieczkowski (1995) views "scientific tourism" as a form of eco-tourism since it protects environment, motivates individuals or groups to visit various eco-systems under the leadership of highly qualified scientists.

In a more simple and different way, alternative tourism as a generic term encompasses a range of tourism forms such as 'eco', 'agro', 'farm', 'culture', 'community', 'rural tourism', (Scheyvens, 2002; Weaver, 1991, cited in Aslam, Awang, \& Nor'ain, 2014). For example 'ecotourism', involves environmental and ecological awareness that ensure the conservation and preservation. 'Community tourism', takes place within the local community, who are socio-economically empowered through tourism and 'rural tourism', is found in the countryside with merger of rustic rural life and basic facilities (Page et al., 2001, cited in Aslam, Awang, \& Nor'ain, 2014). Any form of tourism that showcases the rural life, art, culture and heritage at rural locations, thereby it benefits the local community economically and socially as well as enables interaction between the tourists and the locals for a more enriching tourism experience, can be termed as rural tourism. It is multi-faceted and may entail farm/agricultural tourism, cultural tourism, nature tourism, adventure tourism, and eco-tourism.

Furthermore, the forms of alternative tourism can be clearly classified in the following main categories: " i) Cultural and Historical tourism, based on the unique identity of visited site, ii) Health Tourism, depending on the resource and type of facility, iii) Conference-Congress Tourism, depending on the type of activity, and the aim of the meeting, iv) Sports Tourism, based on both excitement and the ability to perform the activity, v) Contact with Nature: Ecotourism activities, based on preserved environment having natural riches and vi) Entertainment Tourism, based on availability of wide range activities depending on amusement" (Spanish Institute for Prospective Technological Studies, 2001; Gartner, 1996; Aslanyurek 1984; Lier \& Taylor, 1993; Lawton \& Weaver 2001; cited in Christou 2012).

While, Elli Fragkaki (2003) points out five categories: i) Conference and Exhibition tourism, i.e. organising conferences and international exhibitions in areas that also offer other facilities, ii) Sports tourism, meaning that tourism can be combined with sport events, training or individual sports, iii) tourism for Religious reasons, including tours to churches, monasteries, religious festivals etc., iv) Cultural tourism which is associated with visits to monuments or cultural events, v) Ecotourism i.e. tourism that combines local economic development, protection of the quality of the environment and promotion of the natural advantages and the history of an area. 
In the following parts for simplicity reasons which serve the aims of this study, the categories of alternative forms of tourism that will be analysed are: Ecotourism, Cultural and Creative tourism. These forms are the basis for the evolution of many types of alternative tourism. The cultural and creative tourism are of our main interest, as recently the gradually transformation of cultural tourism to mass tourism created the need for a shift from the cultural to creative tourism, in order the negative effects which will be induced to the regions by the resurgence of mass tourism, to be restrained.

\subsection{Ecotourism}

Ecotourism has become the fastest growing sector of the tourism industry. Ecotourism developed in 1970s and 1980s within the boom of the environmental movement which was taking actions against the negative impact of mass tourism to environment. The environmental movement recognized that nature is essential to human well-being. Recently, this belief has been enhanced by science confirming that biodiversity is necessary both for human well-being and survival. Gradually, demand for nature-based experiences of an alternative nature, that mass tourism didn't provide, increased. Less developed countries found the optimal solution to their problems in the face of nature-based tourism as they realized that it offers a means of earning foreign exchange without destroying their natural resources. Many of these countries identified ecotourism to be a useful tool that serves conservation and development goals (Blamey, 2001).

Hector Ceballos-Lascurain is well known as the first who introduced the term 'ecotourism' to designate forms of ecological tourism. He points out ecotourism as a form of travel in which the natural environment is in priority and this is the starting point in considering ecotourism as a specific form of alternative tourism. This travel is to unspoilt natural environments and is predominantly for experiencing the natural environment (Wearing \& Neil, 2009). Ross and Wall (1999), in their article on ecotourism, refer to the role of ecotourism as a strategy in order to preserve natural areas while simultaneously promote their sustainable development. They found associations between ecotourism and sustainability and between conservation and development as are presented in Figure 1.

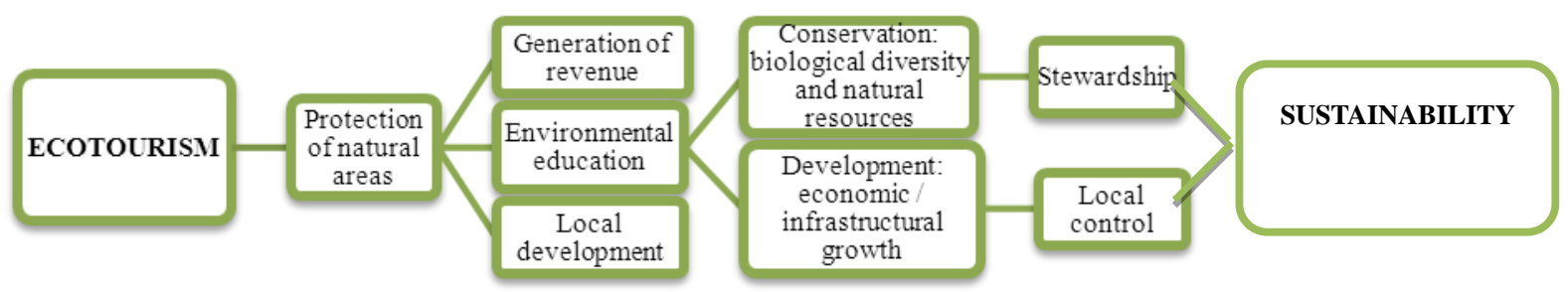

Figure 1. Ecotourism \& sustainability

Source: Ross, Wall, 1999; cited in Cheia, 2013 (p. 57).

Ecotourism can be broadly defined as the nature based tourism that does not conclude in the negative environmental, economic and social impacts that are associated to mass tourism. 


\section{MIMacrothink}

World Journal of Business and Management

ISSN 2377-4622

2017, Vol. 3, No. 1

The definition of ecotourism as have been recently revised by "The International Ecotourism Society" (TIES, 2015) is the "responsible travel to natural areas that conserves the environment, sustains the well-being of the local people, and involves interpretation and education". Literature highlights three principles that this form of tourism followed in its initial period. The first is that ecotourism is non-consumptive and non-extractive in the use of resources for and by tourists, eliminating negative externalities. The second that motivates people ecological conscience and the last is, its eco-centric values and ethics in relation to nature.

TIES, (2015) argues that "Ecotourism is about uniting conservation, communities, and sustainable travel. This means that those who implement, participate in and market ecotourism activities should adopt now the following ecotourism principles:

1) Minimize physical, social, behavioral, and psychological impacts.

2) Build environmental and cultural awareness and respect.

3) Provide positive experiences for both tourists and hosts.

4) Offer direct financial benefits for conservation.

5) Produce financial benefits for both local people and private industry.

6) Deliver memorable interpretative experiences to tourists that help raise sensitivity to host countries' political, environmental, and social climates.

7) Design, construct and operate low-impact facilities.

8) Recognize the rights and spiritual beliefs of the locals and work together to create empowerment".

Ecotourism in recent years, encloses many tourist forms focused on natural environment. The multi-dimensionality of ecotourism requires their distinction. Wearing and Neil (2009) support that "there are number of levels which distinguish the relationship between specific tourism activities and nature. Those activities (experiences):

a) that are dependent on nature, b) that are enhanced by nature, c) for which the natural setting is incidental".

Thus, ecotourism embraces "nature tourism”, “wilderness tourism”, “low impact tourism' and "sustainable tourism".

\subsection{Cultural and Creative Tourism}

As an alternative form of tourism, cultural tourism debouched as a response to mass tourism. It implies the travel for discovering and learning more about monuments and places of historical and artistic interest. WTO (2004) reveals that cultural tourism is one of the largest and fastest growing global tourism markets. It has developed to become a significant phenomenon in the travel and tourism industry and an essential element of the tourism system (Ritzer, 1999; Urry, 2001 cited in Liu, 2014). 


\section{Macrothink}

In the past, culture was not strongly related to tourism, which was considered as a leisure activity. In Europe, the majority of wealthy people was viewing holidays as time for rest and relaxation and only small numbers of them, mostly academics, used to engage in cultural tours with specific educational goals. This situation changed during the 20th century, as tourists became more educated and started seeking new experiences on their vacation time. In addition, more regions began to recognize the value of culture as a potential means of generating tourism (Richards \& Wilson, 2007). Today, tourism and culture are inseparable. According to OECD "Culture and tourism have a mutually beneficial relationship which can strengthen the attractiveness and competitiveness of regions and countries. Culture is increasingly an important element of the tourism product, which also creates distinctiveness in a crowded global marketplace. At the same time, tourism provides an important means of enhancing culture and creating income which can support and strengthen cultural heritage, cultural production and creativity" (OECD, 2009).

The attempts of defining cultural tourism are rather problematic, as it consists of two elements that their definitions also are not clear: "culture" and "tourism". In addition, the growth of cultural tourism, coming from the prevalence of both wider and strong, social and economic trends dominated in "postmodernity" period, generated a variety of terms used both in literature and in policy statements. "Cultural tourism, heritage tourism, arts tourism, ethnic tourism and a host of other terms seem to be almost interchangeable in their usage, but it is rarely clear whether people are talking about the same thing" (Richards, 2003). Bonink in 1992 concluded in two major approaches (Richards, 1996). The first which is "the sites and monuments" approach, referring to the type of attractions that cultural tourists visit, is a product-based definition of culture. The cultural attractions of a country or region are basically seen as physical cultural sites of high tourism value. This approach is mainly used to a quantitative research on cultural tourism, but its drawback is that restricts the analysis to specific sites, that relate cultural tourism to the concept of "high tourism" and to the consumptions of cultural products. Whereas it is important its involvement in cultural process to be examined. These sites or attractions that consider to be attraction poles of cultural tourists (according to ECTAR, 1989, cited in Richards, 1996) are:

- archaeological sites and museums

- $\quad$ architecture (ruins, famous buildings, whole towns)

- $\quad$ art, sculpture, crafts, galleries, festivals, events

- music and dance (classical, folk, contemporary)

- drama (theatre, films, dramatists)

- language and literature study, tours, events

- religious festivals, pilgrimages

- complete (folk or primitive) cultures and sub-cultures.

Munsters in 1996, presents a similar approach in his attempt to classify a wide range of 


\section{$\Lambda$ Macrothink}

cultural tourism attraction in the Netherland and Belgium (Richards, 2003):

I. ATTRACTIONS
a) Monuments
b) Museums
c) Routes
d) Theme parks

\section{EVENTS}
a) Cultural-historic events
b) Art events
c) Events and Attractions

The second approach is the conceptual approach, and is more clearly process-based as it tries to describe the motive and meanings fasten to cultural tourism activity. In this concept, cultural tourists learn about the products and process of other cultures. Tourists increasingly visit destinations for experiencing lifestyles, everyday culture and customs of the inhabitants.

Thus, ATLAS' Cultural Tourism Research Project in 1991 made an effort to combine the two aforementioned approaches resulting to the fact that a product-based definition is necessary for the measurement of cultural tourism, whereas a process-based conceptual definition is also required for the description of cultural tourism as an activity. ATLAS suggested two forms of definition: 1) The "conceptual" definition which is "the movement of persons to cultural attractions away from their normal place of residence, with the intention to gather new information and experiences to satisfy their cultural needs", and 2) The "technical" definition: "All movements of persons to specific cultural attractions, such as heritage sites, artistic and cultural manifestations, arts and drama outside their normal place of residence". Their difference is that the conceptual definition considers the motivation of tourists as central (Richards, 1996) and is the most widespread one. People visit cultural attractions, other than the ones of their habitual place of residence in order to obtain sufficient information and knowledge, fulfilling by the same time their own cultural demands, are the cultural tourists. Some authors support that not all cultural tourists 'consume' culture, satisfying their own cultural needs in the same way ; some tourists have a more superficial, and even accidental, contact; others a more profound one (Silberberg, 1995 cited in Jovicic, 2014). As the level of interest in cultural attractions and events differs among individuals, it is possible to distinguish various categories of cultural tourists. McKercher and Du Cros in 2002 proposed a broad typology that has been rather accepted by the academics, (Jovicic, 2014). Following this typology, the five types of cultural tourists are:

1) The highly motivated cultural tourist.

2) The sightseeing tourist (visiting only the main tourist attractions). 


\section{Macrothink}

3) The casual cultural tourist (conventional interest in culture).

4) The incidental cultural tourist (culture contact/experience is rather superficial and not of main interest).

5) The accidental cultural tourist (although culture is not an interest, the contact/ experience with culture gains the tourists impression).

These five types can be classified in two key groups: The first one includes those tourists whose main motivation is culture. The second group refers to the tourist for whom culture is only complementary, secondary or even accidental (Jovicic, 2014).

In recent years, the dynamic growth of cultural tourism can be characterized by the fast growth of demand for trips to various cultural attractions and amenities. A rise in interest of tourists both to distant cultures and to the local heritage occurred through the increase of educated people around the world and globalization. Moreover, technology supported this growth, and especially internet as a main source of information on cultural attractions for giving the possibility to tourists to create their own cultural tourism products by for example combining travel, accommodation, and attractive contents into tailor-made packages, ignoring specialist tour operators. Technology has influenced deeply tourist consumption as cultural sites are now experienced individually through the earpiece of an audio guide or the viewfinder of a camcorder (Jovicic, 2014). The cultural tourist, from consumer is transforming to producer of the cultural products and experiences. The cultural tourists now have acquired more knowledge about the experiences that they are consuming than the people who supply them, thus taking the lead in experience production. The experiences in which they engage, they are related to a shift from tangible to intangible tourism resources (see Figure 2) implying a transition from static attractions towards more interactive and intangible experiences. These experiences are associated to local culture and not to global one (Richards \& Wilson, 2007).
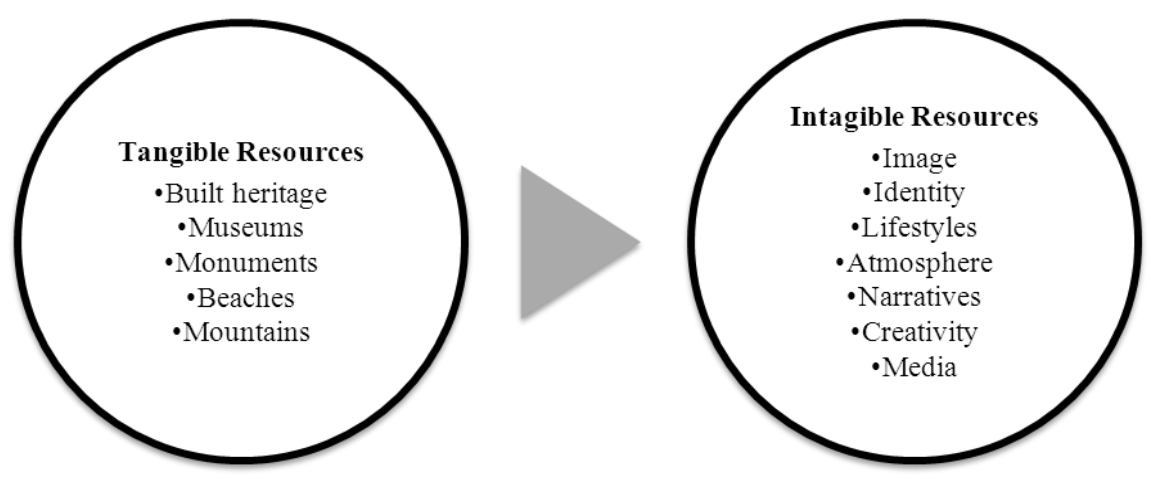

Figure 2. Shift from tangible to intangible tourism resources

Source: Richards, 2007 (p. 18).

As culture tourists become more interactive and creative, cultural tourism needs to be 
repositioned and become more "creative". Although, this new form of tourism is difficult for the traditional tourism sector to deal with, it reveals great opportunities in providing alternative sources of revenue for regions. Traditional cultural tourism, in recent days, turned to be more similar to mass tourism than to alternative one, as famous sites attracted large numbers of tourists, degrading the quality of experience and pushing 'serious' cultural tourists away. Moreover, many places in order to develop a unique image followed similar to mass tourism strategies resulting in making them looking the same in the eyes of cultural tourists. Many tourists are seeking now "alternative" forms of tourism associated to knowledge and based to skills, in "new spots" of the region, away from the traditional cultural heritage. Today, tourists visit places both for their creative atmosphere and the opportunity of doing creative activities themselves. The new challenge for the regions globally is to detect ways of incorporating creativity and making tourists to believe that they are in "the unique place" they desire for their quality holidays. According to Richards (2012), the ways that creativity can be used in tourism include: "tourism products and experiences, revitalization of existing products, valorizing cultural and creative assets, providing economic spin-offs for creative development, using creative techniques to enhance the tourism experience, creating buzz and atmosphere". Therefore, through these ways creativity could support the effort of places to acquire their uniqueness and to evolve their cultural tourism to a "creative" one (see Figure 3).

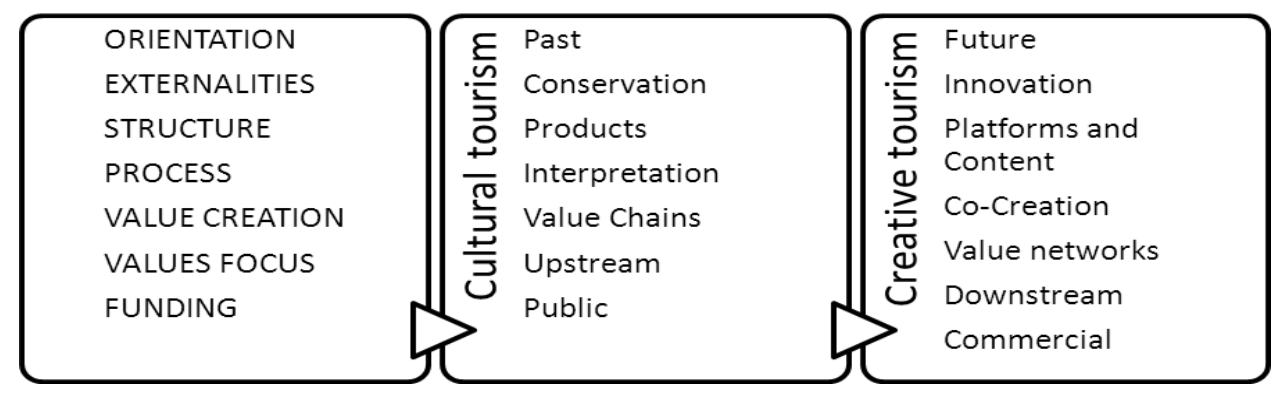

Figure 3. Cultural tourism's transition to creative

Source: OECD, 2014 (p. 53).

According to UNESCO (2006), "Creative Tourism is considered to be a new generation of tourism. The first generation was beach tourism, in which people come to a place for relaxation and leisure; the second was cultural tourism, oriented toward museums and cultural tours. Creative Tourism involves more interaction, in which the visitor has an educational, emotional, social, and participative interaction with the place, its living culture, and the people who live there. They feel like a citizen. This third generation requires that managers also evolve, recognizing the creativity within their city as a resource, and providing new opportunities to meet the evolving interests of tourists". Creative tourism has a greater degree of commercial supply and participation whereas cultural tourism is basically managed or funded by the public sector of each country.

Richards and Raymond (2000) defined the new concept of "creative tourism" as: tourism 


\section{Macrothink}

which offers visitors the opportunity to develop their creative potential through active participation in courses and learning experiences which are characteristic of the holiday destination where they are undertaken, (Richards \& Wilson, 2007). Richards, considers "creative tourism as a type of holiday devoted to learning a particular skill which belongs to a culture of the host country" giving the example "of a growing number of courses in areas such as languages, gastronomy, and art in recent years, driven not only by high demand for creative skills, but also by a growing number of creative producers who have started to service this market" (Richards \& Wilson, 2007).

In fact, "creative tourism" can be broadly defined as the co-creation of creative experiences with tourists (Richards, 2011). There are many ways that this co-makership between guests and hosts can occur, developing creative tourism experiences (see Table 2).

Table 2. Creative tourism experiences

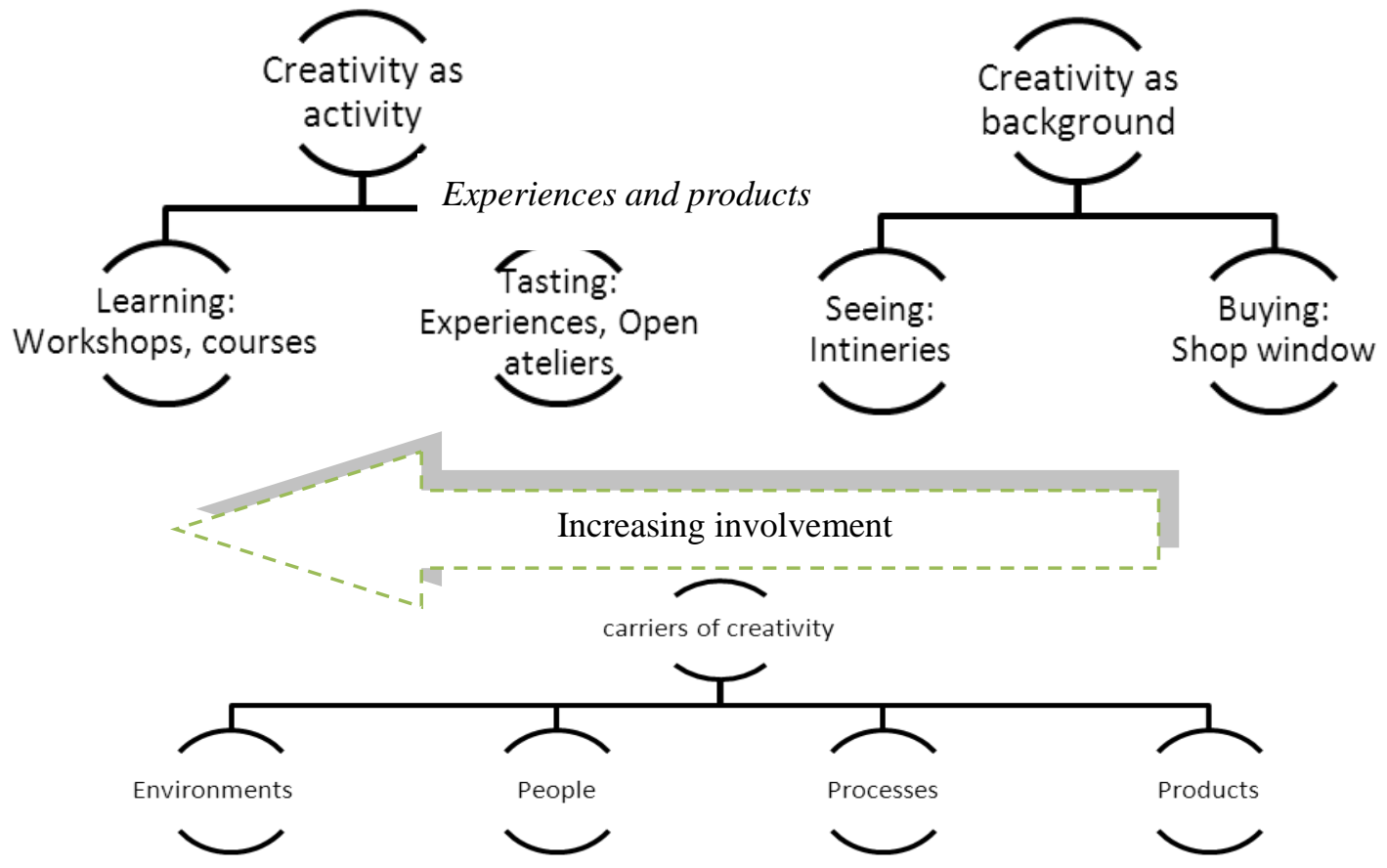

Source: Richards, 2011 (p. 1239).

According to Richards (2009) "these types of experiences can be delivered in a variety of ways, including the creation of networks, itineraries, courses and events" (see table 3). The development of value in the creative tourism system leads to a shift towards wider value networks rather than restrictive value chains, and the production of value follows a downstream distribution and application of content rather than upstream content generation (OECD, 2014). 
Table 3. Types of experiences in creative tourism - examples

\begin{tabular}{|c|c|}
\hline $\begin{array}{l}\text { Creative } \\
\text { Tourism } \\
\text { Networks }\end{array}$ & $\begin{array}{l}\text { - Creative Tourism Network in the city of Nelson, New Zealand provides a wide } \\
\text { range of creative experiences with a range of hands-on workshops run by local } \\
\text { tutors, such as bone carving, Maori language classes, weaving, felting and } \\
\text { woodwork and New Zealand gastronomy. } \\
\text { - Barcelona's Creative Tourism Network adopts a more artistic approach. Through a } \\
\text { platform, potential creative tourists select the types of creative activities they are } \\
\text { interested in, by getting in touch with local creative sector actors. They are } \\
\text { responsible for providing to tourists the facilities or resources to make it happen. }\end{array}$ \\
\hline & $\begin{array}{l}\text { Referring to spaces that offer learning experiences to visitors in different parts of world. } \\
\text { - In Italy, the Italian coffee producer "illy's Università del Caffè established in } 1999 \\
\text { courses on all aspects of coffee and coffee making at } 11 \text { different locations. } \\
\text { - In Southern France, "L'Ecole du Grand Chocolat" owned by the Valrhona chocolate } \\
\text { company, provides similar courses for gourmets and professionals. } \\
\text { - In Barcelona's creative sector, different forms of accommodation provide new } \\
\text { experiences to visitors. } \\
\text { i) In the Chic and Basic hotel, young local designers have the chance to promote } \\
\text { their products through special organized fashion shows in hotel's } \\
\text { individually designed bedrooms. } \\
\text { ii) A 'hostelArt' programme, being running by The Equity Point hostels, } \\
\text { introduces young visitors to the creative sector in Barcelona through small } \\
\text { exhibitions of young artist work in hostel rooms. } \\
\text { iii) The Camping House Barcelona pioneers in providing to its visitors the } \\
\text { opportunity to acquire the experience of design and of stay in a camping in } \\
\text { the urban center. }\end{array}$ \\
\hline Events & $\begin{array}{l}\text { Strategy to develop creative tourism through new types of events which establish the } \\
\text { "active" involvement of creative producers and others in the "co-creation" of events. } \\
\text { Organizing also an event may add an intangible element to the physical culture of the city } \\
\text { - Sidmouth Festival in UK, provides a setting where groups of enthusiasts proceed } \\
\text { in co-creation of unique experiences } \\
\text { - Edinburg Festival is recognized as "creative destination" attracting an important } \\
\text { number of "creative visitors" whose main interest is in culture. } \\
\text { - Umea, a city located in Sweden, was voted as The European Capital of Culture in } \\
\text { 2014. The city's authorities took the decision the cultural program to be planned } \\
\text { and programmed by locals and not by 'experts'. Pursuant to above decision, the } \\
\text { local school children established a blog to be used as the basic script for an opera } \\
\text { performance to which they were later invited. The audience is activated in } \\
\text { producing experience and not being passive just consuming. } \\
\text { In the local Festival "The Festes de Gràcia", the locals decorate and give a theme to } \\
\text { each street of this Barcelona district using recycled materials, such as water } \\
\text { bottles and milk cartons. Creativity is rather high, forming new space. }\end{array}$ \\
\hline
\end{tabular}




\begin{tabular}{|c|c|}
\hline & $\begin{array}{l}\text { A means of linking together creative enterprises and events, and making visitors } \\
\text { engaging in different activities in a certain place. } \\
\text { - In Northern Portugal is found "The Craft Route" of the Alto Minho, including a } \\
\text { large number of crafts producers working from home. The visitors, according to } \\
\text { brochure and website, can visit these producers although in reality this is } \\
\text { infeasible, especially for non-Portuguese speakers as the contact with them is } \\
\text { occurring only through a telephone line. Therefore, the tourist board decide to } \\
\text { sell craft products in its information centers. Sales are supported by } \\
\text { demonstrations from crafts producers during the high season. This strategy } \\
\text { increases the craft sales making the producers satisfied. } \\
\text { The Council of Europe develops a new approach to cultural itinerary concept, } \\
\text { named a 'Cultural Corridor' scheme. Its definition is: Networks of interaction } \\
\text { and economic exchange based on culture and creativity, incorporating principles } \\
\text { of sustainability, fairness and inclusion, based on wide stakeholder partnerships } \\
\text { which are rooted in solid institutional frameworks that stimulate regional } \\
\text { socio-economic development. The key element is the creation of networks, } \\
\text { moving beyond physical routes linking cultural sites in order to include the full } \\
\text { range of creative assets in a region. Culture Corridor scheme focuses in South } \\
\text { East Europe. }\end{array}$ \\
\hline & $\begin{array}{l}\text { - Santa Fe in New Mexico is considered as a "creative" city. The "creative" } \\
\text { atmosphere is dominant in the place, providing a comprehensive range of } \\
\text { creative experiences to the visitors. } \\
\text { - Shanghai and Beijing, trying to be "creative" are developing creative clusters which } \\
\text { are opened up and marketed to visitors. }\end{array}$ \\
\hline
\end{tabular}

Note. Adjusted from Richards (2009, 2011).

Concluding, regions must stop giving their full attention to their tangible assets in order to attract tourists and must shift their policy to the development and valorizing of intangible factors, such as planning, knowledge development and networking, which are necessary to support the cultural or creative tourism system. They must focus on the different elements of the creative system, such as the spaces and events that support the networks required to embed creativity and make links to creative consumers and producers outside the destination (Richards, 2012). Creative tourism requires careful design, according to the principles of visibility, permeability and flexibility (see Table 4). 
Table 4. Creativity's principles

\begin{tabular}{|c|}
\hline Visibility \\
\hline -Small-scale producers \\
must make their \\
production visible. \\
- The key players in \\
creative sector need to \\
extend their economic \\
capital by developing new \\
skills in cross-sectoral \\
operation and applying \\
their creative capital to \\
new ventures.
\end{tabular}
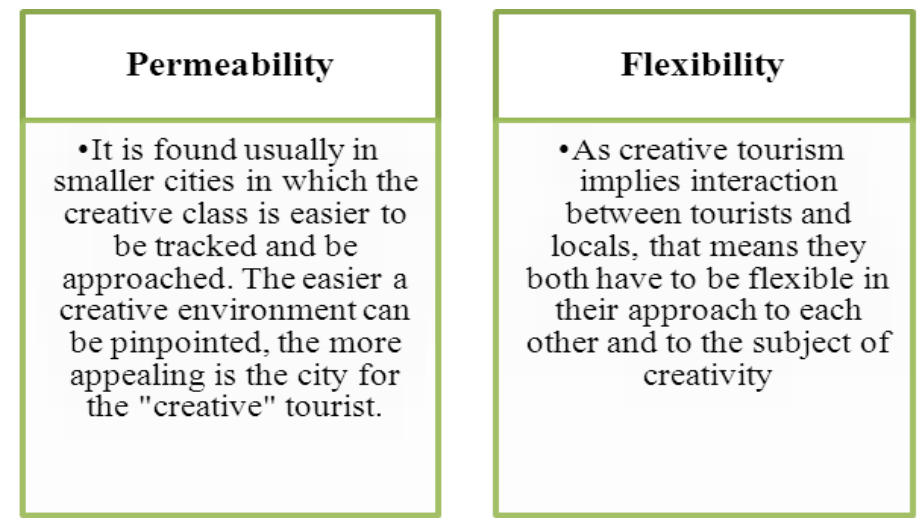

Note. Adjusted from Richards (2012).

If places are careless on their design will fail in incorporating creativity, attracting creative industries and laying the foundations for the sustainable development of "creative" tourism.

The OECD continuously emphasizes the significant contribution of creative industries (CIs) to economic growth and the necessity of region's policy makers to link CIs to tourism. The CIs can drive tourism growth by providing creative tourism experiences, supporting innovative approaches to tourism development, marketing and recreating the image of destinations (OECD, 2014).

\section{Current Issues}

According to OECD Tourism Trends and Policies (2014): "Customer demand for sustainable and eco-friendly tourism products expected to grow but eco-tourism as a significant stand-alone niche sector has been slow to develop".

Visitors demand more individual and authentic experiences and depend more on technology to plan their holidays. The World Wide Web will continue to influence the creative dimension of tourism. The implications of Web 3.0 or mobile Internet are significant for tourism, as tourists use their smartphones or tablets to make bookings, accounting for 54\% of bookings, whereas the travel agencies have fallen to $24 \%$. More widespread access to internet globally has displaced the providers of tourism services to consumers and facilitated the self-guided and independent trips, even to the most remote tourist destinations. The creative innovations in tourism forces the repositioning of the travel system, shifting from a traditional value chain towards a "value web" that includes travel suppliers, consumers, residents, other non-travel actors in a process of travel experience co-creation. The dominance of internet and new media influence the contact between visitors and locals which is now more direct, creating the new phenomenon of "relational" tourism. Tourists will enjoy the experience of "live like a local". This latter trend creates new tourist spaces in many cities and rural regions. The creative industries support the evolution of all these trends (OECD, Tourism and the Creative Economy, OECD studies on Tourism, 2014). 


\section{Conclusions and Recommendations}

In this article we have described the development of tourism market through the alternative forms of tourism. The high criticism of mass tourism and of its negative effects on destination areas gave birth to a new concept of tourism, this of alternative. Alternative tourism incorporated soft tourism, small-scale tourism, green tourism, nature tourism and integrated tourism. Three of the many forms, seemed to be the core of alternative tourism, and as such are distinguished and analyzed.

Ecotourism encloses many tourist forms focused on natural environment and developed in decades of $70 \mathrm{~s}$ and $80 \mathrm{~s}$ within the boom of the environmental movement which was taking actions against the negative impact of mass tourism to environment. Although these forms are closely related to ecotourism are differentiated from it as they reflect different dimensions of the tourism form that is associated with the nature. According to Wearing and Neil, (2009) "there are number of levels which distinguish the relationship between specific tourism activities and nature such as those activities (experiences) that are dependent on nature, those that are enhanced by nature and those for which the natural setting is incidental. Thus, ecotourism embraces "nature tourism", "wilderness tourism", "low impact tourism' and "sustainable tourism".

Cultural tourism is one of the largest and fastest growing global tourism markets. Its dynamic presence in the tourism market can be explained by the fast growth of demand for trips to various cultural attractions and amenities. The increase of educated people globally, the evolution of information and communication technologies (ICTs) revolutionizing the way travel is planned, business is conducted and tourism services and experiences are created and consumed (Neuhofer, Buhalis, \& Ladkin, 2014), boost even further this form of tourism. Now, as the culture tourist is qualified with high educational and technological skills can be more interactive and creative and "produce" his own cultural tourism goods. Thus, the cultural tourism needs to be repositioned and to become also more "creative".

Creative Tourism involves even more interaction, in which the visitor has an educational, emotional, social, and participative interaction with the place, its living culture, and the people who live there (UNESCO, 2006). The new challenge for the regions globally is to detect ways of incorporating creativity and making tourists to believe that they are in the unique place they desire for their quality holidays. Today, tourists visit places both for their creative atmosphere and the opportunity of doing creative activities themselves. Creative tourism requires careful design, with respect to the principles of visibility, permeability and flexibility.

\section{References}

Aslam, M., Awang, W. K., \& Nor'ain, B. H. (2014). Issues and Challenges in Nurturing Sustainable Rural Tourism Development. Tourism, Leisure and Global Change, 1, 75-89. Retrieved from http://geog.nau.edu/igust/Sabah2013/>

Benson, A. (2005). Research Tourism-Professional travel for useful discoveries. In M. Novelli (Ed.), Niche Tourism (pp. 133-144). Oxford: Elsevier. 
https://doi.org/10.1016/B978-0-7506-6133-1.50020-2

Blamey, P. K. (2001). Principles of Ecotourism. In D. B. Weaver (Ed.), The Encyclopedia of Tourism. Wallingford: CABI Publishing.

Butler, R. (1992). Alternative Tourism: The thin Edge of the Wedge. In V. L. Smith, \& W. R. Eadington (Eds.), Tourism Alternatives: Potentials and Problems of Tourism (pp. 31-46). USA: International Academy for the Study of Tourism. https://doi.org/10.9783/9781512807462-006

Cheia, G. (2013). Ecotourism: Defintion and Concepts. Journal of Tourism, (15), 56-60.

Christou, L. (2012). Is it possible to combine mass tourism with alternative forms of tourism: The case of Spain, Greece, Slovenia and Croatia. Journal of Business Administration Online, $\begin{array}{llll}\text { Spring } 2012 . & \text { Retrieved }\end{array}$ http://www.atu.edu/jbao/spring2012/Is_it_possible_to_combine.pdf

Dernoi, L. A. (1981). Alternative tourism: A new style in north-south relations. International Journal of Tourism Management, 2, pp. 253-264. https://doi.org/10.1016/0143-2516(81)90030-X

Dernoi, L. A. (1988). Alternative or community-based tourism. In L. D’Amore, J. Jafari, \& (Eds), Tourism-A vital Force for Peace (pp. 89-94). Vancouver, Canada: D'Amore and Asociates.

Fragkaki, E. (2003). Alternatives Forms of Tourism. Trade with Greece.

Herms, F. (2006). Alternative forms on Gran Canaria.

Holden, A. (1984). Alternative Tourism: Report on the Workshop on Alternative Tourism with Focus in Asia. Bangkok: ECTW.

$\begin{array}{llll}\text { HYPERLINK. } & \text { (n. } & \text { D.). } & \text { Retrieved }\end{array}$ http://www.cabdirect.org/search.html?q=au\%3A\%22Mieczkowski\%2C+Z.\%22

Isaak, R. K. (2010). Alternative tourism: New forms of tourism in Bethlehem for the Palestinian tourism industry. Current Isssues in Tourism, 13(1), 21-36. https://doi.org/10.1080/13683500802495677

Isaak, R. K., \& Hodge, D. (2011). An Explanatory Study: Justice Tourism in Controversial Areas. The Case of Palestine. Tourism Planning \& Development, 8(1), 101-108. https://doi.org/10.1080/21568316.2011.554048

Jovicic, D. (2014). Cultural tourism in the context of relation between mass and alternative tourism. Current Issues in Tourism, 1-8. https://doi.org/10.1080/13683500.2014.932759

Lanfant, M. F. (1980). Introduction: Tourism in the Process of Internationalization. International Social Sciences Journal, 17(1), 14-43.

Lertcharoenchoke, N. (1999). Alternative Tourism. ABAC Journal. Retrieved from http://www.journal.au.edu/abac_journal/may99/article4_f.html 


\section{Macrothink}

World Journal of Business and Management

ISSN 2377-4622

2017, Vol. 3, No. 1

Liu, Y. D. (2014). Cultural Events and Cultural Tourism Deveopment: Lessons form the European Capitals of Culture. (Routledge, Ed.) European Planning Studie, 22(3), 498-514. https://doi.org/10.1080/09654313.2012.752442

Macleod, D. V. L (1998) Alternative tourists: A comparative analysis of meaning and impact. In W. Theobald (Ed.), Global Tourism: The Next Decade. Oxford: Butterworth-Heinemann.

Macleod, D. V. L. (2004). Tourism, Globalisation and Cultural Change: An Island Community Perspective. Cleveland: Channel View Publications.

Mieczkowski, Z. (1995). The Environmental issues of tourism and recreation. University Press of America, London

Neuhofer, B., Buhalis, D., \& Ladkin, A. (2014). A Typology of Technology-Enhanced Tourism Experiences. International Journal of Tourism Research, 16, 340-350. https://doi.org/10.1002/jtr.1958

OECD. (1994). Tourism Strategies and Rural Development. Paris: Organisation for Economic Co-Operation and Development.

OECD. (2009). The Impact of Culture on Tourism. OECD Publishing. https://doi.org/10.1787/9789264040731-en

OECD. (2014a). OECD Tourism Trends and Policies 2014. OECD Publishing. https://doi.org/10.1787/20767779

OECD. (2014b). Tourism and the Creative Economy, OECD studies on Tourism. OECD Publishing. https://doi.org/10.1787/22239804

Pearce, D. G. (1992). Alternative Tourism: Concepts, Classifications, and Questions. In V. L. Smith, \& W. R. Eadington (Eds.), Tourism Alternatives: Potentials and Problems in the Development of Tourism (pp. 15-30). USA: International Academy for the Study of Tourism. https://doi.org/10.9783/9781512807462-005

Richards, G. (1996). Cultural Tourism in Europe. Wallingford: CABI.

Richards, G. (2003). What is cultural tourism. In A. Van Maaren (Ed.), Erfogoed voor Toerisme. Nationaal Contact Monumenten.

Richards, G. (2007). Tourism, Culture and Creativity. Centre for Leisure and Tourism Research.

Richards, G. (2009). Tourism development trajectories-From culture to creativity? Acia Pacific Creativity Forum on Culture and Tourism. Jeju Insland, Republic of Korea: Tourism Research and Marketing.

Richards, G. (2011). Creativity and Tourism. The State of the Art. Annals of Tourism Research, 38, 1225-1253. https://doi.org/10.1016/j.annals.2011.07.008

Richards, G. (2012). Tourism, Creativity and Creative Industries. Creativity and Creative Industries in Challenging Times. 


\section{Macrothink}

World Journal of Business and Management

ISSN 2377-4622

2017, Vol. 3, No. 1

Richards, G., \& Wilson, J. (2007). Tourism development trajectories: From culture to creativity? In G. Richards, \& J. Wilson (Eds.), Tourism, Creativity and Development (pp. 1-34). Routledge.

Smith, V. L. (1989). Hosts and Guests: The Anthropology of Tourism (2nd ed.). Philadelphia: Univesity of Pennsylvania.

Smith, V., \& Eadington, W. (1992). Tourism Alternatives: Potentials and Problems in the Development of Tourism. Philadelphia: University of Pennsylvania Press. https://doi.org/10.9783/9781512807462

The International Ecotourism Society. (2015). What-is-ecotourism. Retrieved from http://www.ecotourism.org

UNEP, \& UNWTO. (2005). Making Tourism More Sustainable-A guide for policy makers.

UNESCO. (2006). Towards Sustainable Strategies for Creative Tourism. Santa Fe, New Mexico, USA: UNESCO.

Wearing, S., \& Grabowski, S. (2011). International Volunteer Tourism: One mechanism for Development. PINTO, Henrique (org), 145-165.

Wearing, S., \& Neil, J. (2009). Ecotourism. Impacts Potentials and Possibilities (2nd ed.). Oxford: Elsevier.

Weaver, D. (1998). Ecotourism in the less developed World. UK: CAB INTERNATIONAL.

\section{Copyright Disclaimer}

Copyright for this article is retained by the author(s), with first publication rights granted to the journal.

This is an open-access article distributed under the terms and conditions of the Creative Commons Attribution license (http://creativecommons.org/licenses/by/3.0/). 